\title{
4-1-1998
}

\section{The Structure of Blackstone's Commentaries}

\author{
Alan Watson \\ University of Georgia School of Law, wawatson@uga.edu
}

b

\section{Repository Citation}

Alan Watson, The Structure of Blackstone's Commentaries (1998),

Available at: https://digitalcommons.law.uga.edu/fac_artchop/860

This Article is brought to you for free and open access by the Faculty Scholarship at Digital Commons @ University of Georgia School of Law. It has been accepted for inclusion in Scholarly Works by an authorized administrator of Digital Commons @ University of Georgia School of Law. Please share how you have benefited from this access For more information, please contact tstriepe@uga.edu. 


\title{
The Structure of Blackstone's Commentaries
}

\author{
Alan Watson $\nmid$
}

I don't intend to provide any background information on Blackstone, except to say that he published his treatise in England between 1765 and 1769, and that aside from Chancellor Kent's Commentaries on the Law of the United States, published between 1820 and 1825, Blackstone's work is the only systematic attempt that has been made to present a theory of the whole common law system. Duncan Kennedy.'

I.

Duncan Kennedy's view of Sir William Blackstone's Commentaries on the Laws of England as the first systematic attempt to present a theory of the whole common law system is interesting but wrong. Blackstone himself listed his predecessors, "those who have laboured in reducing our laws to a System": Glanville, Bracton, Britton, the author of Fleta, Fitzherbert, Brook, Lord Bacon, Sir Edward Coke, Dr. Cowell, Sir Henry Finch, Dr. Wood, Sir Matthew Hale. ${ }^{2}$ Certainly their arrangements are not free from defects. In particular, as Blackstone pointed out, the arrangement of Fitzherbert and Brook was alphabetical, and Bacon purposely avoided any regular order. ${ }^{3}$ But that still leaves the other nine. Kennedy's astonishing error, coupled with his lack of interest in the background to Blackstone, leads him to present an explanation of the structure of the Commentaries in purely ideological terms. But things are not that simple. Legal structures, including the structure of legal treatises, have a strong cultural component which can be uncovered only by historical examination. ${ }^{4}$ Much indeed has been written recently on the structure of William Blackstone's Commentaries, most notably by John W. Cairns, who does place the work in its historical context and relates Blackstone's endeavors

$\dagger$ University Professor, University of Pennsylvania. M.A. 1954, LL.B. 1957, Glasgow University; D. Phil. 1980, D.C.L. 1973, Oxford University.

1. Kennedy, The Structure of Blackstone's Commentaries, 28 Buffalo L. Rev. 205, 209 (1979).

2. W. Blackstone, An Analysis of the Laws of England v (Ist ed. 1756).

3. Id.

4. See, e.g., A. Watson, The Making of the Civil Law 62-82, 111-12 (1981). 
to those of his forerunners. ${ }^{5}$ But even Cairns' account is not complete. The purpose of this Comment is to reveal the true foundations of Blackstone's structure.

In one respect, Kennedy is entirely right. The common law itself has no structure; accordingly, Blackstone was obliged to draw the structure of his treatise from some source external to the common law. The question is whether that source is to be sought in the ideology of eighteenth century English society.

The need for structure in a treatise lies in the necessity of communicating information, and information is more easily grasped when presented in an orderly, systematic way. But when law is based on cases it has no obvious system or structure. It is difficult enough to deduce from a number of cases-each dealing with a particular point, and each apparently unrelated to, and independent of, other cases dealing with a different point-the outlines of a legal institution such as "sale." But how, on the basis of individual cases, can one, for example, arrange the institution of "sale" along with other possible institutions such as "hire" and "partnership" to come up with the notion of "contract" (as distinct, say, from the notion of "acquisition of ownership")? And how then is one to classify "contract" within the whole scheme of law?

In fact, there is no way to deduce logically any particular structure if one bases the law solely on decided cases. No help is available internally in the law (except for statutes which in this instance were no adequate basis). But the good news for English legal writers of Blackstone's time was that there was an external model which could be pressed into service to aid in constructing a systematic structure for the law. The bad news was that the model did not fit.

This external model was, of course, Justinian's Institutes, the elementary student textbook which was published by the Byzantine Emperor in 533 A.D. and which was itself largely based, in structure, on the Institutes of Gaius of around 160 A.D. ${ }^{6}$ The success of the model is unparalleled in legal history; its descendants-at times more great-grandchildren than sons and daughters-could be found in countries such as Holland,

5. Cairns, Blackstone, an English Institutist: Legal Literature and the Rise of the Nation State, 4 OXFord J. LEGAL STud. 318 (1984). Cairns provides a full bibliography and discussion of previous scholars. See also, most recently, Lobban, Blackstone and the Science of Law, 30 HIST. J. 311 (1987); Birks \& McLeod, Introduction, in Justinian's InstrTutes 23-26 (P. Birks \& G. McLeod trans. 1987).

6. See, e.g., J.A.C. Thomas, The Institutes of Justinian viii-ix (1975).

7. See, e.g., H. GRotius, INLEIDINGE TOT DE HollandSChE RECHTSGELEERDHEID (1631) (text originally written between 1619 and 1621). 


\section{France, ${ }^{8}$ Scotland ${ }^{9}$ and Germany. ${ }^{10}$}

Nor is this success surprising. Law exists on the level of ideas as well as operating in the market place. Ideas can be borrowed and given a shape tolerable in, if not ideal for, the market place. Law, indeed, develops mainly by borrowing either from another part of the system by analogy or from another system of law. ${ }^{11}$ Throughout many centuries, when continental lawyers had to find a ruling, they looked for it in Justinian's Corpus Juris Civilis. No matter that the political, economic, and religious character of society in fourteenth century Paris or fifteenth century Salamanca or sixteenth century Leipzig or seventeenth century Leiden was very different from that of second century Rome or of sixth century Constantinople; the Corpus Juris Civilis was there to be plundered. Written in a language that was widely understood, it was accessible; detailed as it was, it could provide some solution for most problems. ${ }^{12}$ Similarly, when jurists wished to create a structure for these legal rules they looked for it in the Corpus Juris and found it in the Institutes. The Institutes alone, of the constitutive parts of the Corpus Juris, was arranged systematically; since it was the foundation course for all university legal studies, its structure was well known.

To be sure, European jurists did not find the arrangement of Justinian's Institutes wholly satisfactory. A few details are all that need be given here of the basic structure of Justinian's Institutes. The Institutes, which deals only with private law, is in four books. Book 1 deals briefly with the nature and sources of law, then at length with persons; Book 2, with things and testate succession; Book 3, with testate succession, contracts and quasi-contract; and Book 4, with delict (tort), quasi-delict, actions, and crimes. This division of subject matter was dictated in part not by considerations of logic, but by the practical need faced by Gaius (but already obsolete in the time of Justinian) to have books all of roughly the same length for reproduction on rollers. ${ }^{13}$

Moreover, this division into four books existed in fundamental tension

8. For France (where the law varied from district to district and where law in the pays de droit ecrit was much closer to Roman Law than it was in the pays de droit coutumier), see, e.g., J. MERCIER, REMARQUES DE DROIT FRANÇOIS SUR LES INSTTIUT'FS DE L'EMPEREUR JUSTINIEN (1657) and G. ARGOU, INSTITUTION AU DROIT FRANÇOIS (2 vols. 1692).

9. For Scotland (where much of the law resembled English common law), see, e.g., J. DALRYMPLE, Viscount StaIR, INStITUtions of THE LAW of Scotrland (1681) and, more especially, G. Mackenzie, Institutions of the Law of Scotland (1684).

10. For Germany (where it is enough to single out one of many works which tried to exclude rules of law that derived from Roman law), see G. Beyer, Delineatio Juris Germanici (1718). On Institutes-based treatises, see generally A. WATson, supra note 4, at 62-82; Watson, Legal Change: Sources of Law and Legal Culture, 131 U. PA. L. Rev. 1121, 1127-28 (1983).

11. See, e.g., A. Watson, Legal Transplants: An approach to Comparative law (1974).

12. See A. Watson, The Evolution of Law 66-96 (1985).

13. See, e.g., 2 J. Marquard, Das Privatleben der Römer 812-14 (2d ed. 1886); MayerMaly, Codex, in 1 Der Kleine Pauly: Lexikon der ANTIKe 1237-38 (1979). 
with the distinction made at the beginning of the Institutes' treatment of substantive law: "All the law that we use pertains either to persons, or to things, or to actions."14 The text is not more specific, nor does anything expressly set out later in the Institutes clarify the meaning of this passage. If later jurists were to give it any meaning, they were obliged to hold that Justinian was including succession rights and obligations within the notion of things. Indeed, the distinctions Justinian drew among persons, things, and actions attracted much attention, and created much confusion, among later jurists. One continental jurist, for example, found it necessary to distort his description of Book 4 of the Institutes in order to accommodate the tripartite scheme of persons, things, and actions. Antonius Perezius (1583-1672), writing in an elementary work consisting of questions followed by answers from Justinian's Institutes, described the structure of the Institutes in this way:

What is the subject matter of the Institutes? The law of persons, of things, and of actions. The law of persons is related in book 1. The law of things, books 2 and 3. The law of actions, book $4 .{ }^{15}$

Perezius' description of the law of actions as the subject matter of Book 4 (even though that book also dealt with private wrongs-delict and quasidelict-and criminal law) is particularly noteworthy. As we shall see, Perezius' approach was paralleled by that of English jurists influenced by the structure of Justinian's Institutes.

For indeed, Justinian's Institutes influenced English jurists just as they did Continental and Scottish ones. To be sure, the Institutes lent themselves even less comfortably to the systematization of English law than they did to Continental. Beyond the general dissimilarity of Roman and English law, the main features of English common law which made the Institutes an unreliable model were (a) the prominence of land law as a result of the old feudal system, (b) the intertwining, indeed the notorious inseparability, of substantive law and procedure, (c) the almost nonexistence of a law of contract, and (d) the elementary state of development of tort law. In Roman law, by contrast, there was scarcely any distinction between land and other important things, the substantive law was kept rigorously apart from procedure, and both contract and delict were welldeveloped branches of law.

Nevertheless, the English turned to the Institutes as a structural guide just as the French and the Germans did. Indeed, one of the best records of the history of the Institutes in England is Blackstone's own Analysis of

14. J. INST. 1.2.12.

15. A. Perezius, Institutiones Imperiales, erotematibus distinctae (1634) (in the Prooemium). Unless otherwise indicated, all translations are mine. 
the Laws of England, first published in 1756, which contains a very illuminating "Preface" and "Contents of this Analysis."

In the "Preface," Blackstone discusses those who, before him, attempted to set out English law according to a method, beginning with Glanvil. The first thing to notice is that he dissociates himself from John Cowell, whose Institutiones Iuris Anglicani was first published in 1605. "Dr COWELL hath indeed endeavoured to reduce the Law of ENGLAND, in his Latin Institutions, to the Model of those of JUSTINIAN: And we cannot be surprised, that so forced and unnatural a Contrivance should be lame and defective in it's Execution." ${ }^{\text {"B }}$ Cowell's Institutiones was one of those many works-literally hundreds-on local law, written in the seventeenth and eighteenth centuries in England and elsewhere, and which took Justinian's Institutes as their model and even used the term "Institutes" or "Institutions" in their titles. Cowell's work is rather unusual in that it follows the arrangement of Justinian very precisely: Every chapter in Justinian is paralleled by one in Cowell, and Cowell has none that is not in Justinian. The structure is forced and results in an imbalance in the treatment of the law. Still, that the book enjoyed a considerable success and filled a need is shown by the fact that it was reprinted in 1630, 1664, and 1679 and, moreover, was translated into English by order of an Act of Parliament and thus published in 1651. ${ }^{17}$

The second thing to notice in the "Preface" is that Blackstone claims to have followed, in general, the arrangement of Sir Matthew Hale, The Analysis of the Law: being a Scheme, or Abstract, of the several Titles and Partitions of the Law of England, Digested into Method, which was first published in 1713. To be sure, Hale's work shows, on its face, little apparent influence of Justinian's Institutes. Indeed, in his preface, Hale claimed that he would not make his distribution into common law and statute law nor would he confine himself to the methods or terms of Roman law. ${ }^{18}$

Nevertheless, despite Hale's disavowal of the Roman model, Justinian's influence on his Analysis is evident. Hale said that he divided the law into two kinds:

1. The civil part, which concerns civil rights, and their remedies.

2. The criminal part, which concerns crimes and misdemeanors. ${ }^{19}$

The discussion of crime, however, is minimal, and Hale's Analysis is

16. W. Blackstone, supra note 2 , at v-vi.

17. See, e.g., Coquillette, Legal Ideology and Incorporation I: The English Civilian Writers, 1523-1607, 61 B.U.L. REV. 1, 71-76 (1981).

18. M. Hale, An Analysis of the Givil Part of the Law (1779) (originally published as M. Hale, The Analysis of the Law: Being a Scheme, or Abstract, of the several Titles and Partitions of the Law of England, Digested into Method A3-A4 (1713)).

19. Id. at A4. 
largely confined to one of the two kinds of law, the civil part. The first section of his Analysis begins:

The civil part of the law concerns,

1. Civil rights or interests.

2. Wrongs or injuries relative to those rights.

3. Relief or remedies applicable to those wrongs.

Now all civil rights or interests are of two sorts;-

Jura personarum, or rights of persons.

Jura rerum, or rights of things. ${ }^{20}$

This division into rights of persons and rights of things has an obvious historical relationship with Justinian's: "All the law that we use pertains either to persons, or to things, or to actions."21 Indeed, in section 23, "Concerning the JURA RERUM, and the general division thereof," Hale makes it plain that he includes succession rights and obligations, in Justinianian fashion, within the general notion of "thing." ${ }^{22} \mathrm{He}$ records of jura rerum that "HERE they are considered ABSOLUTELY-in their own nature or kind-and with relation to themselves, or their own nature-and the several interests in them, and transactions of them."2s Among the distinctions he makes is that between "things personal in possession" and "things in action." Of the latter he says:

Things in action are RIGHTS of personal things, which nevertheless are not in possession; as,

Debts DUE, either;

By contract;

By specialty;

By deed of obligation.

By recognizance.

Goods, whereof the party is DIVESTED, or out of possession. RIGHTS of Damages UNCERTAIN; as Covenants broken. Legacies not paid or delivered. Personal Things in CONTINGENCY; as Accounts, and many more.

Also annuities which are partly in possession, for that they are grantable over; and partly in action, because not recoverable but by Action. ${ }^{24}$

Indeed, the influence of Justinian is evident in the very structure of Hale's Analysis. In accordance with Hale's expressed ideas in the first

\footnotetext{
20. Id. at 1 .

21. J.INST. 1.2.12. It is to be observed that the Latin word ius, used by Justinian, means in English both "law" and "right."

22. M. HALE, supra note 18 , at 43.

23. Id.

24. Id. at 45 .
} 
section of his Analysis, section 1 deals with the nature of private law; sections 2 through 22 with the rights of persons; and sections 23 through 38 with rights pertaining to things. These sections have some correspondence with the arrangement of Justinian's Institutes. Thus, Justinian's Book 1 corresponds to Hale's sections 1 through 22, and in particular Justinian, Book 1, titles 1 and 2 are the equivalent of Hale's section 1. Further, Justinian's Books 2 and 3 dealing with things, succession, and contract correspond to Hale's sections 23 through 38 .

The fact of these correspondences should not be taken to imply that Hale found no difficulty in subjecting the English common law to the Roman model. First of all, Hale clearly found it necessary to take pains to keep separate the substantive law from that of procedure. Moreover, Hale had a problem because English law in his time had little common law of contract, and tort law was in its infancy. Hale's solution to the arrangement problem for contract was to include it by subsuming it into the law of things, for instance in section 28 , on the basis that contract law was a method of acquiring things just as much as were succession and judgment, and execution thereon. ${ }^{25}$ Thus, by the time he reached section 38 , Hale had, in effect, covered the first three books of Justinian's Institutes. Finally, Hale had a problem with the treatment of wrongs, which, in the state of the law at the time, could not be kept separate from remedies. Hale's solution to this aspect of the arrangement problem was simply to treat wrongs pertaining to persons or things (whether the wrongs were torts or crimes) together with the remedies therefore in the remaining sections 39 through 54 . Thus, sections 39 to the end correspond to Justinian's Institutes, Book 4.

II.

It was in the historical context of this century and a half of English efforts to import the Justinianian model that Blackstone produced his Commentaries. The structure of those Commentaries has confused other scholars as well as Duncan Kennedy. Stanley N. Katz rather mischaracterizes the contents of Blackstone's volume $1 ;^{26}$ Gareth Jones describes Book 2 as "puzzlingly entitled the Rights of Things";27 John B.

25. This approach to the classification of contract is sufficiently reasonable for it to recur elsewhere, for instance in the French Code Civil of 1804. The third book of the Code Civil, entitled "Different ways in which one acquires property" (articles 711-2283), includes not only succession (articles 718-892) and gift (articles 893-1100) but also contract (articles 1101-1369, 1387-2283), and even quasi-contract, delict and quasi-delict (articles 1370-86). C. crv. (Prat/Europa 1986). Hale's approach is particularly reasonable, of course, in a country like England where contract law was so little developed.

26. See infra note 31 and accompanying text.

27. G. Jones, The Sovereignty of THE LAw xxv (1973). I think Jones' puzzlement is not with the apparent notion that things might have rights. In Book 1, ch. 1, Blackstone gives "rights of things" as his translation of jura rerum. Jones says that the major part of Book 1 deals "with what we would now call constitutional law." See also Katz, Introduction, in 1 W. BLACKSTONE, CommEN- 
Langbein stresses the surprised reaction of the modern reader to the peculiar organization of volume $3 .^{28}$ Kennedy interprets Blackstone's intentions about the structure with no regard for the context in which Blackstone was working. The last says, with regard to the notion of rights:

I am going to argue that it had a particular apologetic significance. But I do not mean to underestimate the other codetermining factors: Hale had used a similar scheme in a short treatise published posthumously in 1703; the "rights of Englishmen" was an important political slogan; Blackstone was familiar with the Roman law legal categories of jus personarum and jus rerum; and 17th and 18th century political thought had developed "natural rights" as its central concept. What was unusual about Blackstone was not that he put rights in the foreground, but the way he related them to "wrongs." 29

Alas, Kennedy does not do much with his "other codetermining factors." There is no sign that he has understood the significance of Hale for Blackstone's approach, far less that of Justinian's Institutes. But Blackstone's structure can be interpreted only in its historical context. Likewise his intentions. Likewise his unconscious ideology.

In fact, Blackstone, having acknowledged his indebtedness to Hale, reverted to the Justinianian scheme which was already widely followed in Scotland and Europe. In particular, as we shall see, he made use of the Justinianian schemes of Hale and of one other jurist whose influence on Blackstone has gone as yet unnoticed: Dionysius Gothofredus. Book 1 of Blackstone's Commentaries treats the nature of law and rights of persons; Book 2, the rights of things; Book 3, private wrongs; and Book 4, public wrongs or crimes. Blackstone sets out the system of these four books in tabular form. ${ }^{30} \mathrm{I}$ shall review the Justinianian models for each of Blackstone's books in turn, considering first the influence of Hale, then the influence of Gothofredus, on Blackstone's arrangement.

The structure of Blackstone's Commentaries (where each book is divided into chapters) follows, in large measure, the scheme of Hale's Analysis, but without the tabulation. Hence the relationship of one chapter to another is not quite so obvious. The influence of Hale is present, for in-

\footnotetext{
TARIES v (photo. reprint 1979) (1st ed. 1765), discussed infra text accompanying note 31.

28. See infra text accompanying note 36 .

29. Kennedy, supra note 1 , at 227 . Curiously, moreover, Kennedy seems to be unaware even of the existence of Blackstone's Analysis, though he prints a version of its contents-but without the joining lines-that appears to be taken from an 1855 version of the Christian edition of Blackstone's Commentaries by "a member of the New York Bar." Id. at 224, 225, 228, 230. Oddly, Kennedy's paper has attracted much approval from the members of the so-called Critical Legal Studies movement, most recently from Tushnet, Critical Legal Studies: An Introduction to its Origins and Underpinnings, 36 J. LEGAL EDuc. 505, 512 \& n.21 (1986), who describes it (with approval) as "relentlessly ahistorical." One might also describe it as "unhistorical." See also Kennedy's treatment, devoid of all historical reality, of the distinction between "rights" and "wrongs." Kennedy, supra note 1, at 221-72.
}

30. Blackstone's tabulation is reproduced infra Appendix A. 
stance, in Blackstone's Book 1. Thus, the separate introduction and Book 1 are arranged as follows:

Sect. I. On the Study of the Law.

Sect. II. Of the Nature of Laws in general.

Sect. III. Of the Laws of England.

Sect. IV. Of the Countries subject to the Laws of England.

Book I

Of the Rights of Persons

Chap. I. Of the absolute Rights of Individuals.

Chap. II. Of the Parliament.

Chap. III. Of the King, and his Title.

Chap. IV. Of the King's royal Family.

Chap. V. Of the Councils belonging to the King.

Chap. VI. Of the King's Duties.

Chap. VII. Of the King's Prerogatives.

Chap. VIII. Of the King's Revenue.

Chap. IX. Of subordinate Magistrates.

Chap. X. Of the People, whether Aliens, Denizens, or Natives.

Chap. XI. Of the Clergy.

Chap. XII. Of the Civil State.

Chap. XIII. Of the Military and Maritime State.

Chap. XIV. Of Master and Servant.

Chap. XV. Of Husband and Wife.

Chap. XVI. Of Parent and Child.

Chap. XVII. Of Guardian and Ward.

Chap. XVIII. Of Corporations.

Katz, in his introduction to Book 1 of the first edition of Blackstone's Commentaries, comments as follows on these categories: "The first [book] deals with what Blackstone called 'the rights of persons,' what a modern lawyer would call constitutional law." 31 This is understandable but not quite accurate. For Blackstone, Book 1 does deal with the law of persons. This should appear, in part at least, from the chapter headings from chapter 14 onwards of the Commentaries. But it is set out with clarity in the tabulation of the Analysis and expressly set forth in chapter 1 of Book 1 of the Commentaries: Natural persons have rights which are absolute or relative: absolute are the rights which appertain "to particular men, merely as individuals or single persons; relative: which are incident to them as members of society, and standing in various relations to each other." 32 It should occasion little surprise that under the heading of the rights of persons a jurist, who was writing at a time when differences of personal status were regarded as of much more importance than they are today, should treat of the rights of Parliament, the king, the king's family,

31. Katz, supra note 27, at v.

32. 1 W. Blackstone, supre note 27 , at 119. 
his council and of subordinate magistrates. If we seek, as we should, an immediate model for Blackstone, we need look no further than Hale's Analysis. ${ }^{33}$ We can find parallel schemes among the jurists of other countries as well. ${ }^{34}$

Book 2 of Blackstone's Commentaries is devoted to the law of things. It corresponds in subject matter to sections 23 through 38 of Hale's Analysis, and thus to books 2 and 3 of Justinian's Institutes. Contract is again subsumed, for instance, in chapter 30 , under the law of things as one means by which property is acquired. ${ }^{35}$

As for Books 3 and 4 of Blackstone's Commentaries, they correspond in subject matter to sections 39 through 54 of Hale's Analysis and precisely to Justinian's Institutes, Book 4.

Langbein begins his Introduction to volume 3 of the first edition of Blackstone's Commentaries:

The peculiar organization of Blackstone's Commentaries will disconcert the modern reader most when he turns to Book III, Of Private Wrongs. One's expectation is that such a volume would treat the substantive law of torts; and a few thin chapters do indeed canvass the rudimentary tort law of the mid-eighteenth century, together with some remedies for injury to property that modern lawyers would mostly assimilate to the law of property. Book III is, however,

33. At the beginning of section one, Hale states that natural persons are considered in two ways, absolutely and in respect of relation. M. HALE, supra note 18 , at 2 . Discussing then the interest a person, absolutely considered, has in himself, Hale says:

The interest which every person has in himself, principally consists in three things, viz.

The interest he has in the safety of his own person. And the wrongs that reflect upon that, are, assaults - affrays - woundings.

The interest he has in his liberty, or the freedom of his person. The injury whereto, is duress, and unlawful imprisonment.

The interest he has in his name and reputation. The injury whereto, is scandal and defamation.

Id. This corresponds precisely to Blackstone's treatment of the absolute rights of natural persons in the Analysis. When in section 2 and subsequent sections Hale comes to deal with rights in respect of relations, he deals with the king, magistrates, husband and wife, and so on. See id. at 3-36.

34. Thus, to take one example from Germany, G. BEYER, supra note 10, Book 1, entitled "On the law of persons," begins:

Ch.1. On the origins of status, of nobles, or townspeople or burgesses, and of country people.

Ch.2. On the rights of nobles in general.

Ch.3. On the duties and functions of nobles, and the distinction into high and low nobility arising therefrom.

And it goes on to such chapters as:

Ch.14. On the rights of merchants.

Ch.15. On the rights of handworkers.

Ch.17. On the rights of innkeepers and tavern keepers.

Ch.24. On morganatic marriage.

Ch.27. On the guardianship of women and absence.

Likewise in France, the different rights and statuses, even of the monarch, are set forth in detail in the long first title of the first book of A. Loisel, InSTITUTES Coustumières (P. Challine ed. 1665) (1st ed. 1605).

35. The sparseness of Blackstone's treatment of commercial law, see G. JoNes, supra note 27, at xxxix, is in keeping with a dependence on Justinian's Institutes. See A. WATSON, supra note 4, at 158. 
primarily devoted to English civil procedure: the jurisdictional allocations among the courts and the procedures for litigating in them.

This odd labeling - we would call it mislabeling if the book were freshly written and so titled-is not without importance, for it reminds us that as late as Blackstone's day, substantive and adjective law were far from disentangled, and English law still illustrated in many ways Maine's aphorism that in primitive legal systems, substantive law is "secreted in the interstices of procedure. . . ."36

But a legal historian who is interested in law both as cultural phenomenon and as social reality is less disconcerted. English tort law was, as Langbein correctly asserts, rudimentary. Blackstone's problem was how, under the influence of Hale's arrangement and also-as is surely becoming clearer-of Justinian's arrangement, to cope with tort law and with procedure in civil actions in general.

We might consider Blackstone's main dilemma as arising under one of two forms. Either he had to treat the English law equivalent of the contents of Justinian's Institutes Book 4, or he had to treat English legal procedure and find some context for it in his system. The dilemma, in either of these forms, existed as soon as the initial decision was reached to treat English legal rights as substantive law, distinct from procedure. ${ }^{37}$ And such a decision almost had to be made by anyone who wished to systematize English law and who was, as Blackstone was, (a) aware of the work of his predecessors, (b) influenced to any extent by the majesty of Roman law, and (c) at all familiar with the books on local law appearing for over a century in Scotland and continental Europe which had followed the model of Justinian's Institutes. Many of these foreign works on local law, as has been said, had even dropped all treatment of procedure. ${ }^{38}$

Blackstone's solution is simple in the extreme. He has been dealing with substantive legal rights. Any action which arises from legal rights does so because of a breach (or alleged breach) of the rights, hence on account of a wrong. Thus, he deals with the law of private actions as the law of private wrongs, and he includes the law of torts under the heading of private wrongs. Here again, it is important to notice that, to some extent, Blackstone had a forerunner in Hale. Indeed, much of the treatment of wrongs by Blackstone is already apparent in the first section of Hale's

36. Langbein, Introduction, in 3 W. Blackstone, Commentaries iii (photo. reprint 1979) (1st cd. 1768). It need not detain us here, but Maine's aphorism, so famous throughout the common law world, is a mistake. It may accurately describe the growth of English law, but not other primitive legal systems, and certainly not archaic Roman law. See Watson, The Law of Actions and the Development of Substantive Law in the Early Roman Republic, 89 LAW Q. REV. 387 (1973).

37. For the inseparability of substantive law and procedure in this period, see supra text accompanying notes $15-16$.

38. But some continental works show the importance of the law of actions. Thus, over one fourth of the total commentary on Justinian's Institutes of the 16th century German jurist Johannes Schneidewin is devoted to the one title, Book 4, title 6, on actions. J. SCHNEIDEWIN, IN QUATUOR Institutionum Imperialium D. JUSTINIANI CommentaRiI (M. Wesenbecius ed. 1632) (1575). 
Analysis. As we have seen, Hale in his preface divided private law into rights and remedies, and at the outset of his first section he talks of remedies as being applicable to wrongs relative to rights. The contrast between rights and remedies is less marked in Hale, but this may be only because he does not group his sections into books, and thus some sections dealing expressly with remedies do not also seem to concern wrongs. One might feel that Blackstone's contrast in book headings, with "Rights" the most prominent word in Books 1 and 2 and "Wrongs" the most prominent word in Books 3 and 4, is overdone, but few academics can avoid the temptation of heightened contrast.

Blackstone could not foresee that the approach he borrowed in part from Hale could be misleading or confusing to the modern reader, precisely because tort law was so insignificant in Blackstone's day that there could be no confusion. Once again, reference to the tabulation for Book 3 of his Analysis makes the main pattern of his thought extremely clear.

The choice for the content of Blackstone's fourth volume needs little discussion since this final volume corresponds precisely in subject matter to the final title (or chapter) of the Institutes. It is not remarkable that Blackstone's treatment of crime occupies a whole volume, while Justinian provides only a single title. Criminal law was a large and important subject in eighteenth century England, as has often been emphasized. ${ }^{39}$ Its significance deserves one volume out of four. Justinian's Institutes (and the Digest as well), on the other hand, reflect the fact that Roman jurists did not concern themselves much with criminal law. ${ }^{40}$

\section{III.}

In many, though not all, respects, the structure of Blackstone's Commentaries can thus be traced to Hale's Analysis. We must, however, look to one more forerunner for Blackstone's use of tabular form, a tabulation for the structure of the Institutes. It is the work of Dionysius Gothofredus (1549-1622) who, until Theodor Mommsen (1817-1903), was perhaps the most celebrated of the editors of the Corpus Juris Civilis.

Gothofredus ${ }^{41}$ uses four main headings in his layout: Personae, Res,

39. See, e.g., G.J. Postema, Bentham and the Common Law Tradition 263-301 (1986).

40. See, e.g., J.A.C. Thomas, Textbook of Roman LAw 4 (1976).

41. Gothofredus' tabulation appears in some, but not all, of his editions of the Corpus Iuris Civilis. (Gothofredus also provided tabulations for the Digest and the Code.) Among those editions seen by me, his tabulation for the Institutes appears in the edition of 1663, published at Amsterdam by J. Blaeu and L. and D. Elzevier under the care of Simon van Leeuwen; in the edition published in Frankfurt am Main and Leipzig in 1705; and in the edition published in Leipzig in 1720. All references in this article are to the edition published by de Tournes at Basel in 1790. A simplified version of the tabulation is reproduced infra Appendix B. There were other explanations in tabular form for the structure of the Institutes. For a tabulation rather different from that of Gothofredus, see $\mathbf{L}$. Mencke, Tractatio Synoptica Institutionum Juris Justinianearum theoreticoPRACTICA, USU MODERNo IMPERI, ET PRAECIPUE SAXONICO, ACCOMODATA (1698). The same author also analyzed the structure of the Digest. See L. Mencke, Tractatio Synoptica 
Actiones, and De publicis Iudiciis, that is, "Persons," "Things," "Actions," and "Public Judgments." And though Gothofredus is following the order of Justinian's Institutes, these four main headings do not correspond to the contents of the four books of the Institutes.

The format of this tabulation and that of Blackstone are obviously related. Gothofredus is, of course, confined within the arrangement of the Institutes: That is what he has to explain. Thus he cannot change the order of the subjects. But this makes his division in the scheme all the more interesting. He does not treat each book of the Institutes separately. $\mathrm{He}$ also does not treat each topic separately, using the headings Persons, Things, Succession, Obligations, Actions, or some similar system. Rather, Gothofredus reverts to the Institutes scheme ${ }^{42}$ of Persons, Things, and Actions, but he adds Public Judgments. Blackstone corresponds closely. Moreover, Persons finishes at the beginning of Book 1. Things occupies what Gothofredus sets out as Books 2 and 3 . And he includes succession and contract as Things, as Blackstone did. But Gothofredus also adds delicts which seems a proper course of treatment. Unlike English law, the Roman law of delict was well developed; given the strict Roman separation of substantive law and procedure, it was not open to Gothofredus to separate delict from the rest of substantive law and treat it with actions under the heading of wrongs. Actions, in the scheme, occupies almost all of Book 4. But there are two peculiarities here. The first is that Justinian's Institutes, Book 4, actually begins with delict, whereas Gothofredus, astonishingly, wrongly attributes Justinian's treatment of delict and quasidelict to Book 3. Gothofredus in effect is giving a significance to Actions similar to Blackstone's in his treatment of Wrongs, his corresponding category. The second is equally surprising and illuminating. Gothofredus, having finished with Actions, concludes with a totally new heading, $D e$ publicis Judiciis, which is given exactly the same importance, as a separate main heading, as Persons, Things, Actions, although it has only a fraction of the length. He opens his short treatment:

On Public Judgments, 18. Which are neither regulated by actions (on which see above), nor have anything in common with other judgments of which we have spoken: for there is a great difference of matter, and in beginning and in carrying them through. ${ }^{43}$

This wording in fact is a paraphrase of Justinian. ${ }^{44}$ Nonetheless, given

PANDECTARUM THEORETICO-PRACTICA JURE COMMUNI USUQUE MODERNO IMPERII, PRAECIPUE SAXONICO, ACCOMODATA (1697).

42. J. INST. 1.2.12.

43. Corpus Iuris Civilis, 51 app. (D. Gothofredus ed. 1790).

44. "Public judgments are neither regulated by actions nor have they anything similar to other judgments of which we have spoken, and there is a great difference both in bringing them and in carrying them through." J. INST. 4.18.pr. 
the heading of the title, Gothofredus could have put this title under the general rubric of actions, as in Justinian's Institutes..$^{45}$ But he did not do so. It seems not at all fanciful to see here another pointer to Blackstone's structure. Gothofredus' scheme has Persons, Things, Actions, and Crime. Blackstone's has Persons and Things (both under the heading of "Rights"), and Actions and Crime (both under the heading of "Wrongs").

If we were now to take Gothofredus' scheme and relate it to the books and titles of Justinian's Institutes, we would have the following:

G: Species $=J:$ Book 1, titles 1-2

G: Personae $=J$ : Book 1, titles 3-26

$G:$ Res $=J:$ Books 2 and 3

$G:$ Actiones $=J:$ Book 4, titles 1-17

G: De publicis Judiciis $=J:$ Book 4, title 18

And we have seen this exact breakdown of Justinian's Institutes elsewhere, precisely in the Introduction and four books of Blackstone's Commentaries. Thus,

$J:$ Book 1, titles 1-2 = B: Intro ${ }^{48}$

$J:$ Book 1, titles 3-26=B: Book $1^{47}$

$J:$ Books 2 and $3=B$ : Book $2^{48}$

$J:$ Book 4, titles $1-17=B$ : Book $3^{48}$

$J$ : Book 4 title $18=B$ : Book $4^{50}$

Gothofredus had made the division into an introduction and four main headings. Following the structure of Justinian, Gothofredus could not

45. J. INST. 1.2.12.

46. Justinian, Book 1, titles 1 and 2, deals with the nature of justice and jurisprudence, the study of law, and the types of law as natural, of all peoples (ius gentium), or particular to the Romans. Blackstone's Introduction deals with the study of law, the nature of law in general and of English law in particular, and the jurisdiction of English law. Certainly, Blackstone has an introduction before his Book 1 on the law of persons, whereas Justinian incorporates his introductory material in his Book 1 , which deals otherwise only with the law of persons. However, by the conventions of his day, Justinian could not have an introduction separate from a book. In addition, Blackstone's Introduction and Book 1 together make up the first of his four volumes, and in his earlier Analysis Blackstone included his introductory matter as part of Book 1.

47. Justinian, Book 1, titles 3-26 (that is, the remainder of Book 1), concerns the law of persons, as does Blackstone, Book 1. It is worth remembering here that books in the ancient world had, of necessity, a minimum and maximum length, and that in earlier times Justinian, Book 1, titles 1 and 2, could never have stood alone as a separate book. Moreover, in his Analysis, Blackstone had included "The Nature of Laws in General" in his Book 1 and had no separate introduction.

48. Justinian, Books 2 and 3 , deals with things (or property), succession and contract. This treatment corresponds in Justinian's scheme at J. INST. 1.2.12 to the law pertaining to things. Blackstone, Book 2, deals with the rights of things (property), and he incorporates succession and the little there was of contract law as means by which property is acquired.

49. Justinian, Book 4, titles 1-17 (that is, all of Book 4 apart from the final title), deals with private wrongs and actions. Blackstone, Book 3, deals primarily with these same topics, using "actions" to mean remedies for civil wrongs (to rights) and including the incipient law of torts.

50. Justinian, Book 4, title 18 (the final title), deals with crimes under the heading De publicis iudiciis, "On public actions." Blackstone, Book 4, deals with criminal law under the heading "Of public wrongs." 
equate headings with books-the disparate size of the subjects discussed was far too great. But the balance of English law was different, and Blackstone took advantage of that and used the scheme to divide his Commentaries into an introduction and the standard four books. ${ }^{51}$

Gothofredus' edition of the Corpus Juris Civilis, as the standard edition of the time, was very accessible to Blackstone, and the connection between his tabular scheme for the Institutes and for Blackstone's Commentaries cannot be denied. The only possible conclusions are that Blackstone made use of Gothofredus' scheme; that Blackstone and Gothofredus had an unknown common model; or that Blackstone relied on an unknown scheme which derived from Gothofredus. ${ }^{52}$ Absolute precision is not needed here. It is enough to know that some such tabular scheme served Blackstone as a model. Indeed, the principle of Occam's razor would indicate, as the simplest hypothesis, that Blackstone took the idea of tabulation and the scheme from Dionysius Gothofredus. ${ }^{53}$

Two points remain to be addressed: the extent of Blackstone's knowledge of Roman law, and the absence of any avowal by Blackstone of influence from Justinian or Gothofredus.

Blackstone's knowledge of Roman law has, to be sure, sometimes been questioned, but he must have known at least enough to borrow the fundamental outline of the structure of his Commentaries from Justinian's Institutes and to use Gothofredus. First, his brother-in-law, James Clitherow, records that he was an assiduous student, favoring particularly the Greek and Roman poets, ${ }^{54}$ so his Latin was at least adequate. Blackstone also was a contender for the Regius Chair of Civil Law in Oxford (probably in 1751-1752), ${ }^{\text {ss }}$ so it seems probable that he had some, if slight, acquaintance with the Corpus Juris Civilis. He also had studied civil law for his degree. ${ }^{56}$ Further, he did own a copy of Justinian's Institutes, which he bequeathed to New Inn Hall and which is now in Balliol College library. ${ }^{57}$ As we have seen, Blackstone also was well aware of the

51. Last of all, another parallelism should be noted. Both Gothofredus and Blackstone have an introductory section. There, to designate the topics covered by the headings "Persons," "Things," etc., Gothofredus uses the generic Objecta. Corpus Iuris CiviLIS, supra note 43 , at 5 . In exactly that place in his scheme, Blackstone has: "The Objects of the Law of England." (No page numbers in original.)

52. Such tabular schemes are not altogether uncommon.

53. But what if we assume, in the absence of direct evidence, that Blackstone did not have access to such a tabular system? Then the situation becomes even more interesting. Given the very great correlation between Gothofredus and Blackstone, no explanation can be drawn from mere chance or coincidence. But Gothofredus sought to make Justinian's Institutes more accessible to contemporaries. If no other connection links Gothofredus with Blackstone, then the connection between Justinian and Blackstone becomes all the more striking. Consciously or unconsciously, Blackstone must have been trying to follow Justinian.

54. Clitherow, Preface, in W. Blackstone, Reports of Sir William Blackstone ix (2d ed. 1828).

55. See, e.g., G. Jones, supra note 27 , at xvi.

56. Clitherow, supra note 54 , at $x$.

57. This volume has the Balliol College shelf number 1550.a.3. 
structure of Cowell's Institutiones Iuris Anglicani and knew that it followed Justinian exactly; ${ }^{68}$ he therefore was very conscious of the structure of Justinian's Institutes. Finally, in Blackstone's time the tabulation of Gothofredus was readily available to anyone interested in the structure of law books and working in a university with a reasonably good library. ${ }^{69}$

There remains the second puzzle. Why does Blackstone say nothing about Justinian or Gothofredus in the Preface to his Analysis when he expresses his indebtedness to Hale and distances himself from Cowell's arrangement? Any answer can only be conjectural. But I make two suggestions. First, Blackstone, here as elsewhere, ${ }^{60}$ is showing his Englishness (an idea that would occur to a Scot). Thus, he is dealing only with those who tried to set out English law systematically. Secondly, he has criticized Cowell for following the arrangement of Justinian, and he feels no need to show his own debt to the same source.

IV.

What must be emphasized for Blackstone's treatment is that he wished to set forth a systematic exposition of English law for teaching purposes. For Blackstone, law based purely on cases had no natural or inevitable or proper structure. To make law systematic (and to prevent English law from appearing uncouth) he had to treat substantive law separately from procedure. Blackstone wished to set English law forth as a system of rights, as indeed legal writers elsewhere had set out their law as a system of rights. But English substantive law was so inextricably interwoven with procedure that procedure had to be dealt with extensively and with regard to the particular legal right. Writers on the law of other countries and territories often could, and often did, omit a treatment of procedure. ${ }^{61}$ Blackstone's way of bringing in procedure was to treat legal procedure as a matter of remedies for wrongs. Hence the dichotomy of treatment: legal rights, legal wrongs. In his treatment he was very much bound to the contemporary legal culture and was especially indebted to Hale. Even more than was Hale, Blackstone was tied into the structure of Justinian's Institutes, which he knew well, in part through the treatment of Gothofredus.

When we review their structure in detail, we see that Blackstone's Commentaries are the direct descendant of Justinian's Institutes, though the treatment of each subject is geared to the English law of Blackstone's

58. See supra text accompanying note 16 .

59. J. TAYlor, Elements of THE Civil LAw (1st ed. 1755) is at times said to be the source of many of Blackstone's allusions to Roman law. See, e.g., G. Jones, supra note 27, at xxxvi. Taylor contains nothing akin to the arrangement of Gothofredus.

60. Thus, even if we leave aside his whole attitude towards English law, we may cite as an example his explanation for the failure to teach English law earlier in universities: He blames the clergy, "many of them foreigners." W. BLACKSTONE, supra note 27, at 19 (Introduction, section 1).

61. See A. Watson, supra note 4, at 29-32. 
day. To be sure, Blackstone does not follow the example of Dr. Cowell and make every chapter correspond to one in the Institutes; but he does depart from Hale in reverting to the overall structure of Justinian. And, to be sure, the extreme dependence of the structure of Blackstone's Commentaries on that of Justinian's Institutes is obscured by' Blackstone's breaking his four books at different points-so as to give adequate treatment to the topics of English law-and by his terminology in the titles of the four books, emphasizing "rights" or "wrongs" to make his arrangement seem systematic. But the breaks between Blackstone's books correspond precisely (with one major exception) ${ }^{62}$ to the breaks in Justinian's Institutes proposed by Dionysius Gothofredus in his analysis of the structure of the Institutes. The influence of Gothofredus on Blackstone extended, moreover, beyond the matter of structure to the manner of presentation: Gothofredus set out his analysis of Justinian's Institutes in a tabular form, an approach followed by Blackstone in his Analysis of the Laws of England, the forerunner to the Commentaries. In all of their efforts, Blackstone, Gothofredus, and Hale were constrained by the peculiarities of the structure Justinian created. Justinian declared in a prominent place in the Institutes that all law pertains to persons, things, or actions, a division which does not correspond to his books. ${ }^{63}$ Gothofredus, Hale, and Blackstone all accept this division as the basis of their own structures, which means they include obligations-only contracts for Hale and Blackstone-and succession rights within the notion of "things." Hale in particular subsumes contracts under "things" as one mode of acquiring property. It is here, with the other main class of obligation, torts, that Blackstone-who follows the approach of Hale before him-breaks with Gothofredus. Gothofredus, reasonably from his theoretical perspective, includes delict as pertaining to things. Blackstone, equally reasonably from his perspective in English law, treats the then-rudimentary tort law along with private actions, which themselves are classified as private remedies for wrongs to rights. As a result, Gothofredus sharply separates delict from the law of actions, while Justinian treats both delict and actions in one of his books and Blackstone does the same with tort and private actions. In his more minor arrangement, Blackstone was, as he says in his Analysis, much influenced by Hale.

No careful scholar can, I think, deny the combined influence on Blackstone's Commentaries of the structure of Justinian's Institutes, of the tabular explanation of that by Dionysius Gothofredus, and of the structure of Hale's Analysis. Blackstone's originality in arrangement lies in his combining these elements each in its sphere to produce a structure satisfactory for the English law of his day. In such circumstances it is difficult to

62. See infra text accompanying note 63 .

63. Cf. supra text accompanying notes 13-15. 
imagine that there was also a particular and precise political ideological motivation for the structure of the Commentaries on the Laws of England. 
Appendix A: Blackstone's Tabulation

Book I.

The Nature of Laws in general. Chapter I.

The Grounds and Foundation of the Laws of England. II.

The Countries subject to those Laws. III.

The Objects of the Laws of England; viz. IV.

I. The Rights of Persons; which are

1. Natural Persons; whose Rights are

1. Absolute; viz, the Enjoyment of

1. Personal Security,

2. Personal Liberty,

3. Private Property.

2. Relative; as they stand in Relations. V.

1. Public; as

1. Magistrates; who are

1. Supreme,

1. Legislative; viz. The Parliament.

2. Executive; viz. The King; wherein of his

VI.

1. Title,

2. Dignity, VII.

3. Duties,

4. Councils,

5. Royal Family,

6. Prerogative, VIII

7. Revenue. IX.

1. Ordinary; viz.

1. Ecclesiastical.

2. Temporal.

2. Extraordinary. $\mathrm{X}$

2. Subordinate, XI.

2. People; who are XII.

1. Aliens.

2. Natives; who are

1. Clergy.

2. Laity; who are in a State. XIII.

1. Givil.

2. Military.

3. Maritime

2. Private; as XIV.

1. Master and Servant.

2. Husband and Wife.

3. Parent and Child. XV.

4. Guardian and Ward.

2. Bodies politic, or Corporations. XVI.

II. The Rights of Things.

Book II.

III. Private Wrongs, or civil Injuries.

Book III.

IV. Public Wrongs, or Crimes and Misdemeanors.

Book IV. 
Book II.

The Rights of Things.

Which consist in Dominion over Chapter I.

I. Things real; in which are considered

1. Their several kinds; viz.

1. Corporeal.

2. Incorporeal. II.

2. The Tenures, by which they may be holden; viz. III.

1. Antient.

2. Modern. IV.

3. Estates therein; with respect to

1. Quantity of Interest; viz.

1. Freehold

1. Of Inheritance. V.

2. Not of Inheritance.

2. Less than Freehold. VII.

2. Time of Enjoyment; in VIII.

1. Possession.

2. Remainder.

3. Reversion.

3. Number and Connexions of the Tenants; who may hold

IX.

1. In Severalty.

2. In Jointenancy.

3. In Coparcenary.

4. In Common.

4. Title to them; which may be gained or lost by $X$.

1. Descent.

2. Purchase; which includes

1. Occupancy. XI.

2. Prescription

3. Escheat.

4. Forfeiture. XII.

5. Bankruptcy.

6. Alienation, by common Assurances; which are

1. Deed, or Matter in Pais; wherein of it's

1. General Nature.

2. Several Species. XIV.

2. Matter of Record. XV.

3. Special Custom. XVI.

4. Devise.

II. Things personal, or Chattels; in which are considered XVII.

1. Their Distribution.

2. Property therein.

3. Title to them; which may be gained or lost by XVIII.

1. Occupancy.

2. Prerogative.

3. Succession.

4. Custom. XIX

5. Marriage.

6. Forfeiture.

7. Judgment.

8. Grant. XX.

9. Contract.

10. Bankruptcy. XXI.

11. Testament. XXII.

12. Administration. 
Book III.

Private Wrongs, or Civil Injuries.

For which the Laws of England have provided Redress Chapter I.

I. By the mere Act of the Parties.

II. By the mere Operation of Law.

III. By both together, or Suit in Courts, wherein II.

1. Of Courts; and therein of

1. Their Nature and Incidents.

2. Their several Distinctions; viz.

1. Of public or general Jurisdiction;

1. The Courts of common Law and Equity.

2. Ecclesiastical Courts. III.

3. Courts military.

4. Courts maritime.

2. Of private or special Jurisdiction.

2. Of the Cognizance of Wrongs, or Injuries, in the Courts. IV.

1. Ecclesiastical.

2. Military.

3. Maritime.

4. Of common Law; wherein

1. Of the respective Remedies, for Injuries affecting

1. The Rights of Persons,

1. Absolute.

2. Relative.

2. The Rights of Property,

1. Personal,

1. Possession; by

1. Dispossession.

2. Damage.

2. In Action; by Breach of Contracts.

2. Real; by VII.

1. Ouster, or Dispossession of

1. A private Subject; from

1. Freeholds.

2. Chattels real. VIII.

2. The King, or his Grantees.

2. Trespass.

3. Nuisance.

4. Waste.

5. Subtraction. $X$.

6. Disturbance.

IX.

2. Of the Pursuit of Remedies, XI.

1. By Action at common Law; wherein of

1. Process.

2. Pleadings.

3. Demurrer and Issue.

4. Trial; by XII.

1. Record.

2. Inspection.

3. Witnesses.

4. Certificate.

5. Wager of Battel.

6. Wager of Law.

7. Jury. XIII.

5. Judgment. XIV.

6. Appeal.

7. Execution.

2. By Proceedings in the Courts of Equity. XV. 
Book IV.

Public Wrongs, or Crimes and Misdemeanors.

In which are considered Chapter I.

I. The general Nature of Crimes, and Punishment.

II. The Persons capable of committing Crimes; and their several Degrees of Guilt, as II

1. Principals.

2. Accessories.

III. The several Crimes (with their Punishments) more peculiarly offending III.

1. The divine Law.

2. The Law of Nations.

3. The municipal Law: Being such as especially affect IV

1. The King and Government; viz.

1. High Treason.

2. Felonies injurious to the Prerogative. V.

3. Praemunire.

4. Misprisions and Contempts.

2. The Commonwealth; viz. Offences against VI.

1. Public Justice.

2. Public Peace.

3. Public Trade.

4. Public Health

5. Public Oeconomy.

3. Individuals; being Crimes against VIII.

1. Their Persons; by

1. Homicide.

2. Other corporal Injuries. IX.

2. Their Habitations. X.

3. Their Property.

IV. The Means of Prevention; by Security for

1. The Peace.

2. The good Behaviour.

V. The Method of Punishment; wherein of

1. The several Courts of criminal Jurisdiction.

2. The Proceedings there; XII.

1. Summary.

2. Regular; by

1. Arrest.

2. Commitment, and Bail.

3. Prosecution; by

1. Presentment.

2. Indictment.

3. Information.

4. Appeal.

4. Process. XIII.

5. Arraignment, and it's Incidents.

6 . Plea, and Issue.

7. Trial, and Conviction. XIV.

8. Clergy.

9. Judgments, and Attainder; which induce $\mathrm{XV}$. 1. Forfeiture.

2. Corruption of Blood.

10. Avoider of Judgment, by

1. Falsifying, or Reversing, the Attainder.

2. Reprieve, or Pardon.

11. Execution. 


\section{Appendix B: Gothofredus' Tabulation}

(Translation.)
Explication of the Arrangement of the Books of the Institutes
Discovered by the Jurist.

Preface, or the enactment confirming these Institutes.

Book I.

On justice and law.

Kinds.

On natural law, law of nations and civil law.

Objects of the law.

\section{Persons}

Slaves

On the law of persons.

Free

On those free born.

On freed persons.

Who cannot manumit, and for what reasons.

On the repeal of the lex Fufia Caninia.

On those Persons who are independent or in another's power.

On persons who are in another's power.

On paternal power.

On marriage.

On adoption.

On the ways of terminating paternal power.

On wards, and their tutors and curators.

Kinds.

Testamentary.

On guardianships.

Those who can appoint tutors by will. 


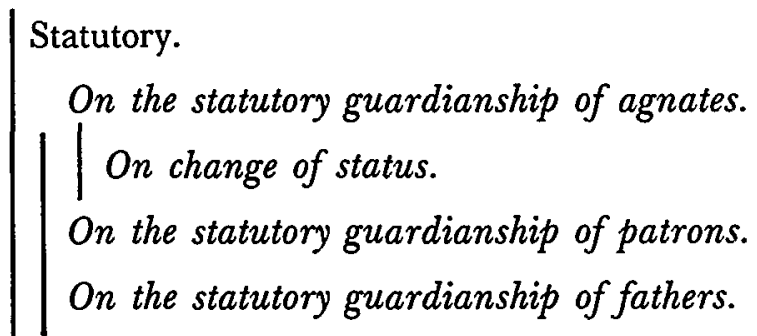

Appointed.

On the Atilian tutor, and that appointed under the lex Julia et Titia.

On the authority of tutors.

Contraries.

On the ways guardianship is ended.

Connections.

On curators.

On security given by tutors or curators.

On excuses for not being tutors or curators.

On tutors or curators suspected of fault.

Book II.

Things.

On the divisions of things, and acquisition of ownership of them by the law of nations.

On corporeal and incorporeal things.

On rustic and urban praedial servitudes.

On usufruct.

On the right of use and habitation.

On the ways of acquiring things by statutory and civil law.

Individual things in these ways.

On usucaption and long term prescription. 


\section{On gifts.}

To whom it is or is not permitted to alienate.

Through which persons one may acquire.

Universal succession.

On making wills.

On the soldiers' will.

On those not permitted to make a will.

On the disinherison of children.

On the appointment of heirs.

On ordinary substitution.

On pupillary substitution.

On the ways in which wills become inoperative.

On the unduteous will.

On the types and differences of heirs.

Reduction of the estate.

On legacies.

On revocation of legacies.

On the lex Falcidia.

On inheritances under a trust and on the S.C. Trebellianum.

On the individual things left by trust.

On Codicils.

On intestate succession.

On the statutory succession of agnates.

On the S.C. Tertullianum.

On the S.C. Orphitianum.

On the succession of relations by blood. 


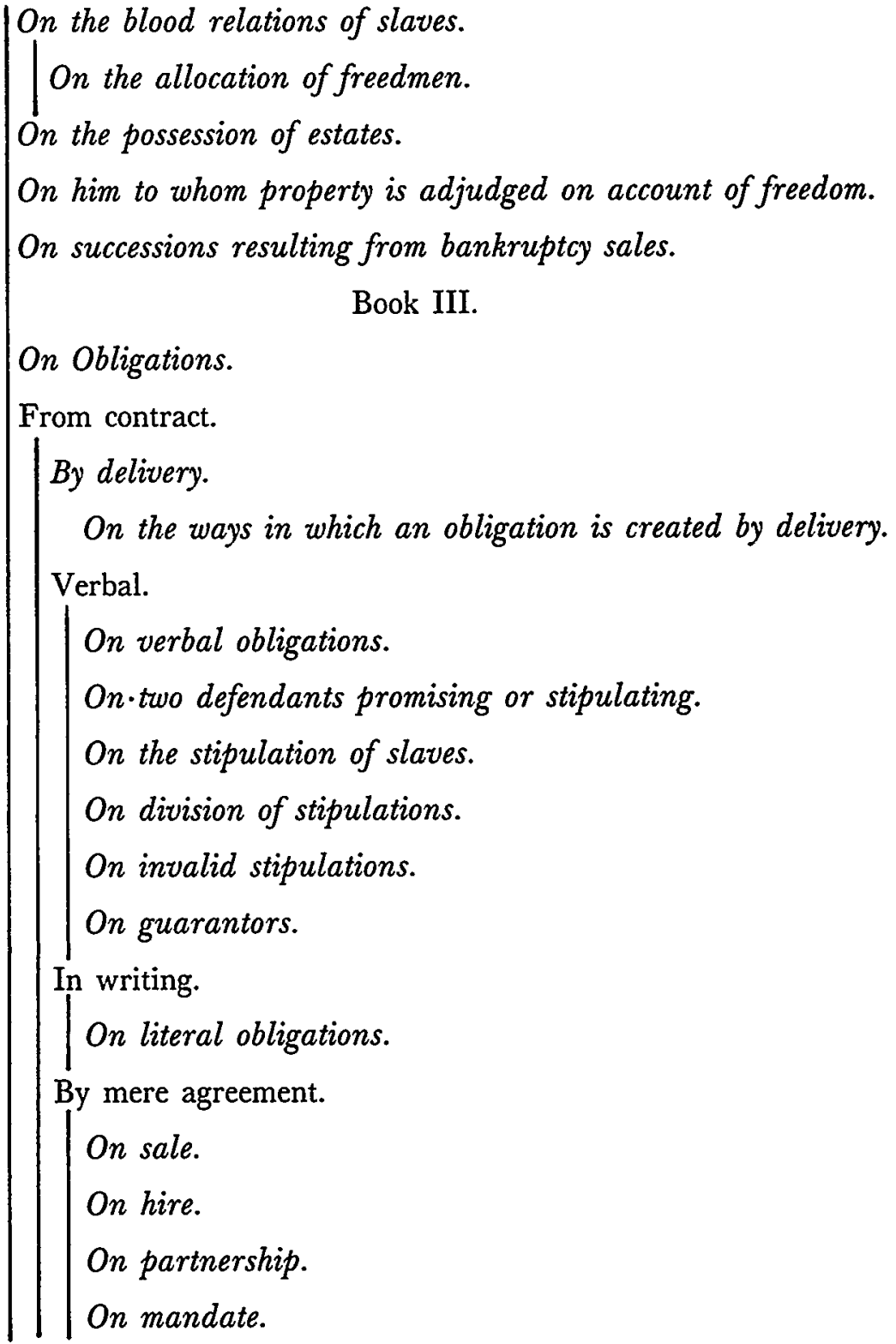




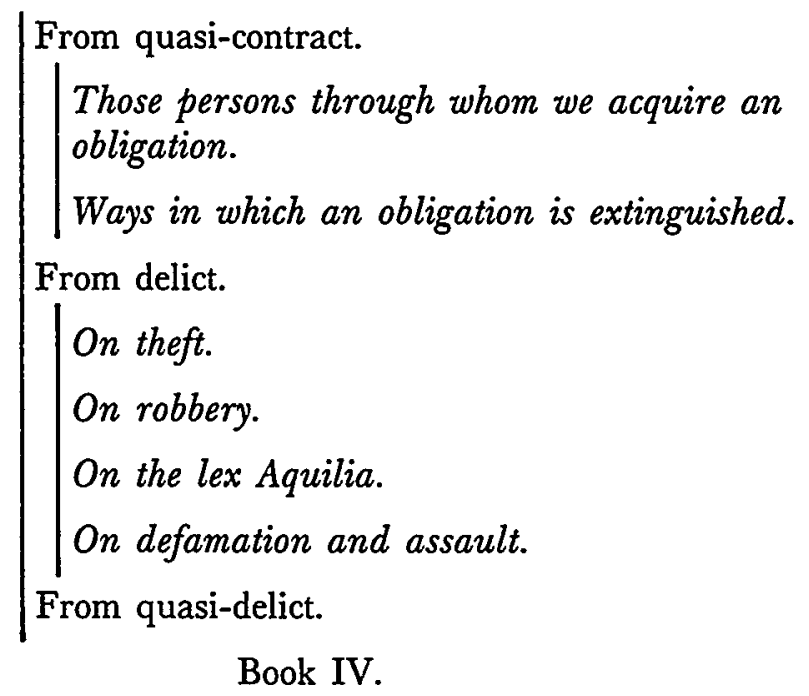

Actions

Plaintiff

On actions.

On actions available to us through the act of persons in another's power.

On transactions with such persons.

On noxal actions.

If a four-footed animal.

On those through whom we can sue.

On security.

On perpetual actions and those with a time limit and on those available to or against heirs.

\begin{tabular}{l|l} 
Defendant. & On special defences.
\end{tabular}

Plaintiff

On replications.

and

Defendant.

1.

On interdicts.

Judge

On the penalty for rush litigation.

On the duty of the judge.

On public judgments. 
HeinOnline -- 97 Yale L.J. 822 1987-1988 